\title{
MIOCENE BRACHIOPODS FROM THE ŽIDLOCHOVICE LOCALITY, CZECH REPUBLIC
}

\author{
Miocenní brachiopodi z lokality Židlochovice, Česká republika \\ Jana Pavézková', Šárka Hladilová2, Maria Aleksandra Bitner ${ }^{3}$ \\ 'Department of Geological Sciences, Faculty of Science, Kotlářská 2, 61137 Brno, Czech Republic; e-mail:jana.pavezkova@seznam.cz \\ ${ }^{2}$ Department of Biology, Faculty of Education, Palacký University, Purkrabská 2, 77140 Olomouc, Czech Republic \\ ${ }^{3}$ Institute of Paleobiology, Polish Academy of Sciences, ul. Twarda 51/55, 00-818 Warszawa, Poland
}

(24-34 Ivančice)

Key words: Carpathian Foredeep, Miocene, Lower Badenian, Moravian, Židlochovice, faciostratotype, Brachiopoda

\begin{abstract}
Miocene brachiopods are reported for the first time from two boreholes, designated as ŻIDL1 and ŽIDL2, drilled in 2010 at the Židlochovice locality (Carpathian Foredeep, Moravia, Czech Republic). Four species, namely Argyrotheca cuneata (Risso, 1826), Argyrotheca sp., Joania sp. and Megathiris detruncata (Gmelin, 1790), have been identified. They are very rare in the studied material and occur mainly in the ŽIDL2 borehole, only A. cuneata has been found in the ŻIDL1 borehole. All the discussed species are common in the Miocene of the Central Paratethys.
\end{abstract}

\begin{abstract}
Abstrakt
V príspěvku jsou prezentovány první nálezy miocenních brachiopodů z lokality Židlochovice (karpatskápředhlubeň, Morava, Česká republika), a to ze dvou nových vrtů, ŽIDL1 a ŽIDL2, které byly na této lokalitě provedeny v roce 2010. Byly zjištěny celkem 4 druhy brachiopodů, a to Argyrotheca cuneata (Risso, 1826), Argyrotheca sp., Joania sp. a Megathiris detruncata (Gmelin, 1790). Vyskytují se poměrně velmi vzácnè a v malém počtu jedincủ, byli nalezeni zejména ve vrtu ŽIDL2, pouze druh A. cuneata se objevil i ve vrtu ŽIDL1. Všechny zjištěné druhy jsou běžné v miocénu Centrální Paratethydy.
\end{abstract}

\section{Introduction}

The Židlochovice locality, one of the richest Miocene paleontological fossil sites in Moravia, represents the faciostratotype of upper part of the Lower Badenian - Moravian sequence (Tertiary - Neogene - Miocene, Cicha in Papp et al. 1978). Intensive geological and paleontological studies were conducted since the middle of the $19^{\text {th }}$ century (e. g. Hörnes 1856-1870, Procházka 1893, Cicha et al. 1956, among others). Rich marine fauna and flora have been described, namely foraminifers, radiolarians, bryozoans, ostracods, molluscs (bivalves, gastropods, cephalopods), echinoids, corals, sponges, fish otoliths, calcareous red algae and nannoplankton (Procházka 1893, Cicha in Papp et al. 1978, Sváček 1995, Zágoršek 2010, Tomaštíková 2011, Tomaštíková - Zágoršek 2012, Seko 2011, Seko et al. 2012). A unique discovery of a complete lower whale jaw of Cetotherium sp. has been made by Musil (1957).

Brachiopods represent infrequent group of fossils in Neogene sediments of the Carpathian Foredeep and Vienna Basin. The brachiopod fauna has not been mentioned from Židlochovice so far. This study was performed within the Bc. thesis (Pavézková 2012) based on the two new shallow ŽIDL1 and ŽIDL2 boreholes drilled at this locality in 2010 (Grant Project 205/09/0103, Grant Agency of the Czech Republic).

The boreholes are situated in an old brickyard on the SW slope of the Výhon hill on the northern margin of the town of Židlochovice. Lower Badenian sediments (clayey marls, marls, and algal limestones) of the Carpathian Foredeep have been cored. The ŽIDL1 borehole reached depth of $12 \mathrm{~m}$ (GPS position: $49^{\circ} 02.498^{`} \mathrm{~N}, 016^{\circ} 37.318^{`} \mathrm{E}$,
$230 \mathrm{~m}$ ) and the ŽIDL2 borehole depth of $17 \mathrm{~m}$ (GPS position: $49^{\circ} 02.496^{`} \mathrm{~N}, 016^{\circ} 37.380^{`} \mathrm{E}, 246 \mathrm{~m}$ - Tomaštíková - Zágoršek 2012).

\section{Methods}

Brachiopods were studied in 2011-2012 by the first author within her Bc. thesis (Pavézková 2012) based on the washed residues used for the diploma theses by Tomaštíková (2011) and Seko (2011) who investigated bryozoans and ostracods, respectively. The samples of the weight $0.5-1.0 \mathrm{~kg}$, collected from the ŽIDL1 borehole (13 samples) and ŽIDL2 borehole (8 samples), were mechanically disintegrated, boiled in water with sodium carbonate, washed in the Retch AS 200 sieving machine (fractions $2 \mathrm{~mm}, 1 \mathrm{~mm}$ and $0.063 \mathrm{~mm}$ ), and desiccated in the MEMMERT apparatus at the temperature up to $90^{\circ} \mathrm{C}$. The brachiopods were manually picked under the Nikon binocular microscope and their shells were cleaned in the Retsch UR1 ultrasonic cleaner. The photographs were made in the Leica MZ16 stereomicroscope. All laboratory works were done at the Department of Geological Sciences, Faculty of Sciences, Masaryk University in Brno.

\section{Results}

Four brachiopod taxa have been recognized in the ŽIDL1 and ŽIDL2 boreholes.

Phylum Brachiopoda Duméril, 1805

Subphylum Rhynchonelliformea Williams, Carlson, Brunton, Holmer and Popov, 1996 
Class Rhynchonellata Williams, Carlson, Brunton, Holmer and Popov, 1996

Order Terebratulida Waagen,1883

Suborder Terebratellidina Muir-Wood, 1955

Superfamily Megathyridoidea Dall, 1870

Family Megathyrididae Dall, 1870

Genus Argyrotheca Dall, 1900

Type species: Terebratula cuneata Risso, 1826

Argyrotheca cuneata (Risso, 1826)

(Fig. 1)

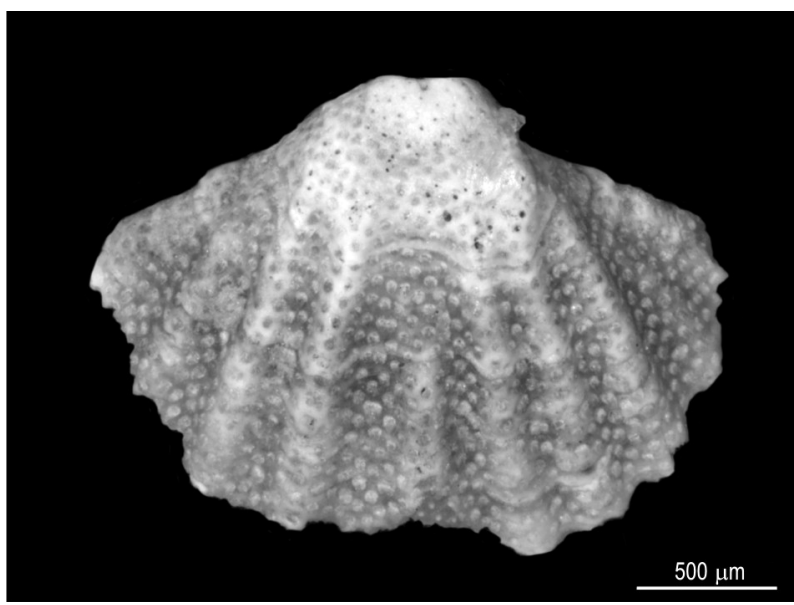

Fig. 1 - Argyrotheca cuneata (Risso, 1826), ventral valve, ŽIDL2, $11.6-11.8 \mathrm{~m}$.

1889 Cistella squamata Eichw.; J. Dreger, p. 186, pl. 1, figs. 12-14.

1977 Argyrotheca squamata Eichwald, 1830; W. Barczyk and E. Popiel-Barczyk, p. 163, pl. 2, fig. 1.

1990 Argyrotheca cuneata (Risso, 1826); M. A. Bitner, pp. 138-140, text-figs. 5-6, pl. 4 figs. 1-9 (cum syn.).

1993 Argyrotheca cuneata (Risso, 1826); M. A. Bitner, pp. 149-150, pl. 2, figs. 1-6, pl. 3, figs. 1-6.

2000 Argyrotheca cuneata (Risso, 1826); M. A. Bitner and A. Pisera, 9, pl. 1, figs. 1-7.

2004 Argyrotheca cuneata (Risso, 1826); M. A. Bitner and A. Kaim, p. 196, figs. 2A-C.

2012 Argyrotheca cuneata (Risso, 1826); K. Zágoršek et al., p. 275 ; figs. $6 \mathrm{~A}, \mathrm{~B}$.

Material: 2 dorsal valves (ŽIDL1, 8.4-8.5 m), 1 complete shell and 1 ventral valve (ŽIDL2, 11.6-11.8 m), 2 fragments (ŽIDL2, 8.7-8.8 m), 2 fragments (ŽIDL2, $11.6-11.8 \mathrm{~m})$.

Remarks: The shell is small, transversely subrectangular with a long hinge line and a triangular area truncated by a large hypothyrid foramen. The shell surface is covered with single, low, rounded ribs, with a median groove where a short intercalated rib is present. Distinct pores are visible. The complete shell represents a juvenile individual.

Distribution: Argyrotheca cuneata is a very common species in the Miocene strata of the Central Paratethys. So far it has been reported from the Miocene strata of Bulgaria (Bitner 1993), Poland (Barczyk - Popiel-Barczyk 1977, Bitner 1990, Bitner - Pisera 2000, Bitner - Kaim 2004), Hungary (Bitner - Dulai 2004, Dulai 2007), Austria (Kroh 2003), and Italy (Seguenza 1866, Davidson 1870). In the
Czech Republic it has been mentioned from Rudoltice (Dreger 1889), Kralice nad Oslavou (Bitner et al. 2013), and Přemyslovice (Zágoršek et al. 2012). Today A. cuneata occurs in the Mediterranean Sea and eastern North Atlantic at depth from 5 to $645 \mathrm{~m}$ (Brunton - Curry 1979; Logan 1979, 1993; Álvarez - Emig 2005).

Argyrotheca sp.

(Fig. 2)

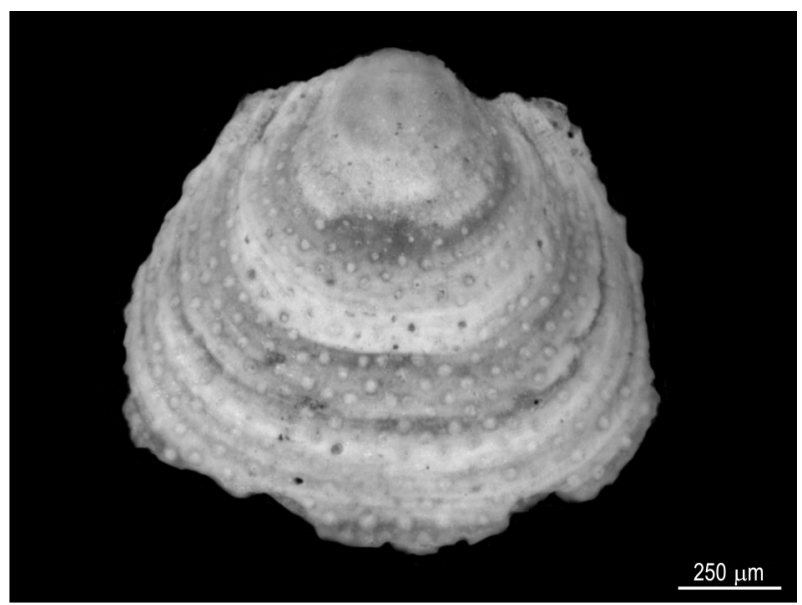

Fig. 2 - Argyrotheca sp., ventral valve, ŽIDL2, 8.7-8.8 m.

Material: 1 ventral valve (ŽIDL2, 8.7-8.8 m).

Remarks: The valve surface is smooth, with poorly defined growth lines, clearly representing a young individual of Argyrotheca, however, a very limited material precludes any precise determination.

Genus Joania Alvarez, Brunton and Long, 2008

Type species: Terebratula cordata Risso, 1826

Joania sp.

(Fig. 3)

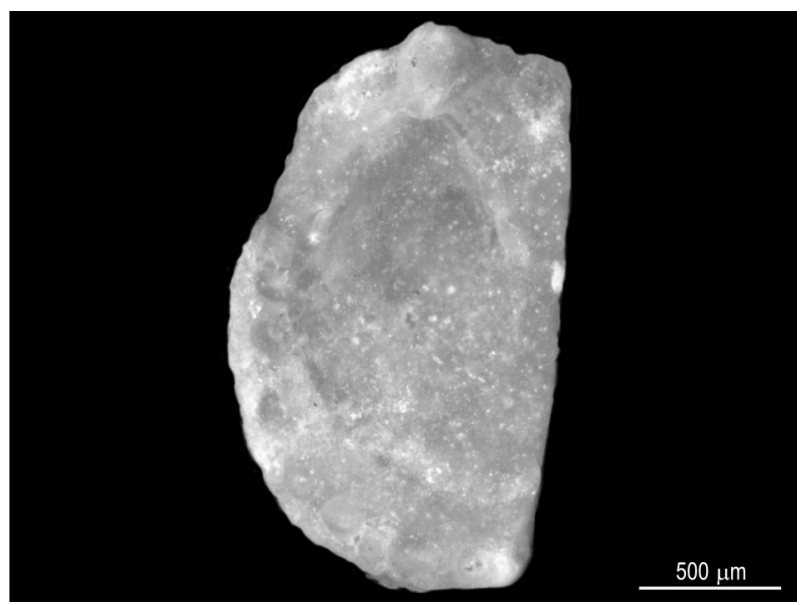

Fig. 3 - Joania sp. dorsal valve, ŽIDL2, 11.6-11.8 m.

Material: 1 broken dorsal valve (ŽIDL2, 11.6-11.8 m).

Remarks: The valve is small, thin, smooth, with conspicuous growth lines and with a high median septum. Based on the presence of submarginal tubercles this specimen was attributed to Joania, a genus newly erected by 
Álvarez et al. (2008). The material is too poorly preserved for species determination.

Genus Megathiris d'Orbigny, 1847

Type species: Anomia detruncata Gmelin, 1790

Megathiris detruncata (Gmelin, 1790)

(Fig. 4)

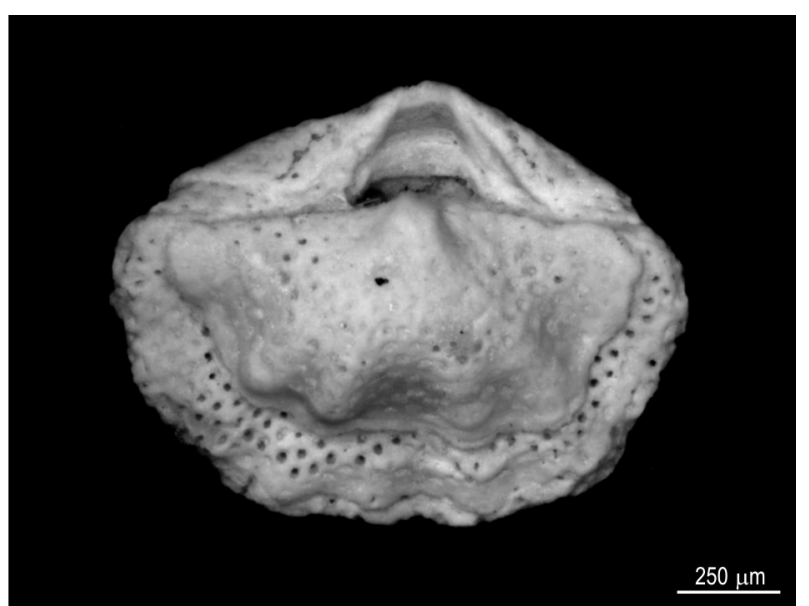

Fig. 4 - Megathiris detruncata (Gmelin, 1790), complete shell, ŽIDL2, 11.6-11.8 m.

1889 Argiope decollata Chemnitz.; J. Dreger, p. 183-185; pl. 1, figs. 1-5.

1977 Megathiris detruncata (Gmelin, 1790); W. Barczyk and E. Popiel-Barczyk, p. 164, pl. 1, figs. 4-5.

1990 Megathiris detruncata (Gmelin, 1790); E. PopielBarczyk and W. Barczyk, p. 175-177, text-figs. 10-11, pl. 6, figs. 6-11, pl. 7, figs. 1-13.

1990 Megathiris detruncata (Gmelin, 1790); M. A. Bitner, p. 135-138; text-figs. 3-4; pl. 3, figs. 1-8; pl. 6, figs. 1-7 (cum syn.).

2003 Megathiris detruncata (Gmelin, 1790); A. Kroh, p. 147, pl. 1, figs. 4-6.

2012 Megathiris detruncata; K. Zágoršek et al., p. 275, figs. $6 \mathrm{D}, \mathrm{E}$.

Material: 1 complete shell (ŽIDL2, 11.6-11.8 m).

Remarks: The shell outline is transversely elongate with a long straight hinge line. The shell surface is ornamented by a few broad ribs. Internally, this species is characterized by the presence of two lateral septa.

Distribution: This species is one of the most common in the Middle Miocene strata of the Central Paratethys (see Barczyk - Popiel-Barczyk 1977, 1990; Bitner 1990; Kroh 2003; Bitner - Dulai 2004; Dulai 2007). Recently, it was also noted from Přemyslovice and Kralice nad Oslavou in the Czech Republic (Zágoršek et al. 2012; Bitner et al. 2013). M. detruncata is known since the Eocene and today it lives in the Mediterranean Sea and the eastern North Atlantic. Its extant representatives occur at depths from 16 to 896 m (Brunton - Curry 1979; Logan 1979, 1993; Álvarez - Emig 2005).

\section{Discussion}

These brachiopods are reported for the first time from the Židlochovice locality, Moravia, Czech Republic. Four species, namely Argyrotheca cuneata, Argyrotheca sp., Joania sp. and Megathiris detruncata, have been identified in the studied material. Most brachiopods come from the ŽIDL2 borehole, only the species A. cuneata has been found in the ŽIDL1 borehole. All the species described here are common and well known in the Miocene deposits of the Central Paratethys.

Newly discovered brachiopods from Židlochovice supplement our knowledge of brachiopods in the Moravian part of the Carpathian Foredeep (Czech Republic). In the species composition, the Židlochovice assemblage is comparable to those from Přemyslovice and Kralice nad Oslavou, where Argyrotheca cuneata, Joania cordata and Megathiris detruncata have been recorded. On the other hand, only one species, i. e. Joania cordata, is in common with the Hluchov locality (Bitner, oral communication). A more detailed evaluation of all these findings will be the subject of a future study.

\section{Conclusions}

The investigated brachiopod fauna from Lower Badenian sediments of two boreholes, ŽIDL1 and ŽIDL2, respectively, in Židlochovice, Moravia, Czech Republic, contains four species, all belonging to the family Megathyrididae. The species Argyrotheca sp., Joania sp. and Megathiris detruncata (Gmelin, 1790) were found only in the ŽIDL2 borehole, while Argyrotheca cuneata (Risso, 1826) occurs in both boreholes. However, brachiopods are very rare in both boreholes, A. cuneata being most numerous.

All species recognized in Židlochovice are common at other Miocene Paratethyan localities with brachiopods. Typically, the Megathyrididae family dominates in the brachiopod assemblages of the Central Paratethys (cf. Bitner 1990, 1993; Popiel-Barczyk - Barczyk 1990; Bitner - Pisera 2000; Dulai 2007; Dulai - Stachacz 2010). Extant representatives of Megathyrididae are mostly shallow water, exhibiting cryptic mode of life (Logan 1979).

\section{Acknowledgements}

The financial support of the Grant Agency of the Czech Republic (205/09/0103) is gratefully acknowledged. We wish also to thank the reviewers Doc. J. Michalik and Mgr. T. Lehotský for their useful comments to the manuscript. 
References

Álvarez, F. - Emig, C. C. (2005): Brachiopoda. - In: Álvarez, F. - Emig, C. C. - Roldán, C. - Viéitez, J. M. Ramos, M. A. et al. (eds.): Fauna Ibérica, 27, Lophophorata, Phoronida, Brachiopoda. Museo Nacional de Ciencias Naturales, CSIC, pp. 57-177.

Álvarez, F. - Brunton, C. H. C. - Long, S. L. (2008): Loop ultrastructure and development in recent Megathiridoidea, with description of a new genus, Joania (type species Terebratula cordata Risso, 1826). - In: Cusack, M. - Harper, D. A. T. (eds): Brachiopod Research into the Third Millennium. - Earth and Environmental Science Transactions of the Royal Society of Edinburgh. 98, 391-403.

Barczyk, W. - Popiel-Barczyk, E. (1977): Brachiopods from the Korytnica basin (Middle Miocene; Holy Cross Mountains, Poland). - Acta Geologica Polonica, 27, 157-167.

Bitner, M. A. (1990): Middle Miocene (Badenian) brachiopods from the Roztocze Hills, south-eastern Poland. - Acta Geologica Polonica, 40, 129-157.

Bitner, M. A. (1993): Middle Miocene (Badenian) brachiopods from coral reefs of north-western Bulgaria. - Acta Geologica Polonica, 43, 147-155.

Bitner, M. A. - Dulai, A. (2004): Revision of Miocene brachiopods of the Hungarian Natural History Museum, with special regard to the Meznerics collection. - Fragmenta Palaeontologica Hungarica, 22, 69-82.

Bitner, M. A. - Kaim, A. (2004): The Miocene brachiopods from the silty facies of the intra-Carpathian Nowy Sącz Basin (Poland). - Geological Quarterly, 48, 193-198.

Bitner, M. A. - Pisera, A. (2000): Brachiopod fauna from the Middle Miocene deposits of Niechobrz, south-eastern Poland. Tertiary Research, 20, 7-15.

Bitner, M. A. - Zágoršek, K. - Hladilová, Š. (2013): Deep-water brachiopod assemblage from the Middle Miocene of Kralice nad Oslavou, Moravia, south-eastern Czech Republic. - Comptes Rendus Palevol, 12, 2, 81-89.

Brunton, C. H. C. - Curry, G. B. (1979): British brachiopods. - Synopses of the British Fauna (New Series), 17, 1-64.

Cicha, I. - Paulík, J. - Tejkal, J. (1956): Poznámky ke stratigrafii miocénu jz. části vněkarpatské pánve na Moravě. - Sborník Ústředního ústavu geologického, Oddíl paleontologický, 23, 307-364.

Davidson, T. (1870): On Italian Tertiary Brachiopoda. - Geological Magazine, 7/8-10, 359-370, 399-408, 460-466.

Dreger, J. (1889): Die tertiären Brachiopoden des Wiener Beckens. - Beiträge zur Paläontologie und Geologie Österreich-Ungarns, 7, 179-192.

Dulai, A. (2007): Badenian (Middle Miocene) micromorphic brachiopods from Bánd and Devecser (Bakony Mountains, Hungary). - Fragmenta Palaeontologica Hungarica, 24-25, 1-13.

Dulai, A. - Stachacz, M. (2011): New Middle Miocene Argyrotheca (Brachiopoda; Megathyrididae) species from the Central Paratethys. - Földtani Közlöny, 141, 283-291.

Hörnes, M. (1856): Die fossilen Mollusken des Tertiär-Beckens von Wien. I. Gastropoden. - Abhandlungen der Geologischen Reichsanstalt, 3, 1-736.

Hörnes, M. - Reuss, A. E. (1862-1870): Die fossilen Mollusken des Tertiär-Beckens von Wien. II. Bivalven. - Abhandlungen der Geologischen Reichsanstalt, 4, 1-479.

Kroh, A. (2003): The Brachiopoda of the Langhian (Lower Badenian) of the Molasse Zone and the northern Vienna Basin. - Annalen des Naturhistorischen Museums in Wien, 104A, 145-153.

Logan, A. (1979): The Recent Brachiopoda of the Mediterranean Sea. - Bulletin de l'Institut océanographique Monaco, 72, 1-112.

Logan, A. (1993): Recent brachiopods from the Canarian-Cape Verdean region: diversity, biogeographic affinities, bathymetric range and life habits. - Courier Forschungsinstitut Senckenberg, 159, 229-233.

Musil, R. (1957): Předběžné sdělení o nálezu velryby v židlochovickém miocénu. - Časopis Moravského musea, Vědy přírodní, $42,52-64$.

Papp, A. - Cicha, I. - Seneš, J. - Steininger, F. et al. (1978): Chronostratigraphie und Neostratotypen, Bd. VI, Miozän M4 - Badenien (Moravien, Wielicien, Kosovien). - VEDA, 594 pp.

Pavézková, J. (2012): Ramenonožci z vybraných badenských lokalit karpatské předhlubně na Moravě. - MS, Bachelor Thesis, Př́rodovědecká fakulta Masarykovy univerzity. Brno.

Popiel-Barczyk, E. - Barczyk, W. (1990): Middle Miocene (Badenian) brachiopods from the southern slopes of the Holy Cross Mountains, Central Poland. - Acta Geologica Polonica, 40, 159-181.

Procházka, V. J. (1893): Miocaen židlochovický na Moravě a jeho zvířena. - Česká Akademie pro vědy, slovesnost a umění. 90 pp.

Seguenza, G. (1866): Interno ai Brachiopodi miocenici della provincie piemontesi. - Atti dell'Academia degli Aspiranti Naturalisti Napoli, Ser. 3, 6, 53-67.

Seko, M. (2011): Ostracoda lokality Židlochovice. - MS, Diploma Thesis, Přírodovědecká fakulta Masarykovy univerzity. Brno.

Seko, M. - Pipík, R. - Doláková, N. (2012): Early Badenian ostracod assemblage of the Židlochovice stratotype (Carpathian Foredeep, Czech Republic). - Central European Journal of Geosciences, 4, 1, 111-125.

Sváček, P. (1995): Bryozoa spodního badenu jihomoravské části karpatské předhlubně. - MS, Diploma Thesis, Př́rodovědecká fakulta Masarykovy univerzity. Brno.

Tomaštíková, T. (2011): Mechovky z lokality Židlochovice. - MS, Diploma Thesis. Př́rodovědecká fakulta Masarykovy univerzity. Brno.

Tomaštíková, T. - Zágoršek, K. (2012): Mechovky z lokality Židlochovice. - Geologické výzkumy na Moravě a ve Slezsku, 19 , 53-56.

Zágoršek, K. (2010): Bryozoa from the Langhian (Miocene) of the Czech Republic, Part I: Geology of the studied sections, systematic description of the orders Cyclostomata, Ctenostomata and „Anascan“ Cheilostomata (suborders Malacostega Levinsen, 1902 and Flustrina Smitt, 1868). - Sborník Národního muzea v Praze, Řada B - prŕírodní vědy, 66, 1-2, 1-138.

Zágoršek, K. - Nehyba, S. - Tomanová Petrová, P. - Hladilová, Š. - Bitner, M. A. - Doláková, N. - Hrabovský, J. - Jašková, V. (2012): Local catastrophe caused by tephra input near Přemyslovice (Moravia, Czech Republic) during the mid-Miocene. - Geological Quarterly, 56, 269-284. 